\title{
An overview of the emerging warm mix asphalt technology
}

\begin{abstract}
The asphalt industry is constantly attempting to reduce its emissions as concerns are growing on global warming. This is done by decreasing the mixing and compaction temperatures of asphalt mixtures without affecting the properties of the mix which is possible through numerous available technologies in the industry. The production of asphalt mix is done by warm mix asphalt (WMA) technology at considerably lower temperatures $\left(120^{\circ} \mathrm{C}\right.$ or lower). Less energy consumption, lower mixing and compaction temperatures, early site opening, reduced ageing, fewer emissions, cool weather paving, better workability and, finally, an extended paving window could be mentioned as some of the benefits obtained by using the WMA. This paper presents the WMA techniques and technologies such as foaming techniques, wax and chemical additives techniques. Additionally, the performance of WMA popular technologies such as Sasobit ${ }^{\circledR}$, WAM $®-F o a m$, Evotherm ${ }^{\circledR}$, Low energy asphalt, Rediset ${ }^{\circledR}$ WMX and REVIX ${ }^{\mathrm{TM}}$ are fully described.
\end{abstract}

Keyword: Warm mix asphalt; WMA; Sasobit@; Evotherm®; WAM®-Foam 